\title{
Seroprevalence of Cytomegalovirus Among Paediatric Patients with Hearing Loss Attending National Ear Care Centre Kaduna Northwest Nigeria
}

\author{
Edward Isaac Usman ${ }^{1, ~ *, ~ E l a y o ~ S a l i h u ², ~ O g b o i ~ J o h n b u l l ~ S u n n y ~}{ }^{3}$, Musa Abdullahi Maikano, \\ Edward Deborah Shetu ${ }^{5}$, Shallangwa Bata Ishaku ${ }^{4}$, Meshubi Florence ${ }^{1}$, Isaac Agyigra ${ }^{6}$ \\ ${ }^{1}$ Department of Medical Laboratory, Medical Microbiology Laboratory, Federal Neuropsychiatric Hospital, Barnawa, Nigeria \\ ${ }^{2}$ Department of Virology, Federal College of Veterinary and Medical Laboratory Technology, Vom, Plateau State, Nigeria \\ ${ }^{3}$ Research Department Jedima International Health Consult Ltd, Lagos, Nigeria \\ ${ }^{4}$ Department of Animal Health, Federal College of Animal Health and Production Technology, Vom, Plateau State, Nigeria \\ ${ }^{5}$ Department of Virology, Tehilah Medical Laboratory, Sabon Tasha, Kaduna State, Nigeria \\ ${ }^{6}$ Department of Medical Laboratory, Microbiology Unit, National Ear Care Cente, Kaduna State, Nigeria
}

Email address:

ishidi03@yahoo.com (E. I. Usman)

${ }^{*}$ Corresponding author

\section{To cite this article:}

Edward Isaac Usman, Elayo Salihu, Ogboi Johnbull Sunny, Musa Abdullahi Maikano, Edward Deborah Shetu, Shallangwa, Bata Ishaku, Meshubi, Florence, Isaac Agyigra. Seroprevalence of Cytomegalovirus Among Paediatric Patients with Hearing Loss Attending National Ear Care Centre Kaduna Northwest Nigeria. American Journal of Laboratory Medicine. Vol. 2, No. 5, 2017, pp. 90-95.

doi: $10.11648 /$ j.ajlm.20170205.12

Received: February 11, 2017; Accepted: March 7, 2017; Published: October 24, 2017

\begin{abstract}
Cytomegalovirus cause viral congenital infection at any stage of pregnancy leading to congenital defects, which can either be primary or recurrent and hearing loss is one of the common congenital CMV infection occurring in $10-15 \%$ of infected children. This study, therefore examined the seroprevalence of cytomegalovirus among paediatric patients with hearing loss attending National Ear Care Centre Kaduna northwest Nigeria. A total of 77 samples was collected from patients aged between 0-13 years, diagnosed of hearing impairment and screened for Cytomegalovirus IgG and IgM specific antibodies using ELISA method at National Ear Care Centre Kaduna State North West Nigeria. Among the 77 (100\%) patients screened, $35(45.5 \%)$ were male, while $42(54.5 \%)$ were female with mean age $(2.04)$. The study reveavled that, of the total numbers screened, 62 (80.5\%) were IgG specific antibodies positive, while 15 (19.5\%) were IgG specific antibodies negative, and none of the patient were positive for IgM specific antibodies. the result of patients based on their gender status show male patients $21(60 \%)$ were positive while $14(40 \%)$ were negative for CMV IgG specific antibodies. The female is $33(78.5 \%)$ positive and $9(21.4 \%)$ negative for CMV IgG specific antibodies. The findings hearing impairment is associated with cytomegalosvirus showing statistically significant in IgG specific antibodies $(\mathrm{P}<0.05)$, while in IgM it is not statistically significant. Therefore CMV infection is prevalent among patients with Hearing impairment and affect the social economic and political status of the patients.
\end{abstract}

Keywords: Cytomegalovirus (CMV), Hearing Loss, IgG, IgM, Congenital, Antibody

\section{Introduction}

Cytomegalovirus is a member of the Herpes family, which is responsible for a wide range of infections in human of all ages. The Virus causes enlargement of cells in the body, hence the prefix Cytomegalo which means enlarged cell [1].
The Virus is a double stranded DNA with approximate size of $200 \mathrm{~nm}[2,3]$.

The infection occurs at all ages with the Virus has been asymptomatic, while in foetus and neonates it could lead to 
neurological complications and even death $[4,5]$.

The Virus can remain latent in the body, but may subsequently cause severe recurrent infection if an individual immunity is compromised $[5,6]$. Research has proved that Cytomegalovirus causes congenital infection and brain damage leading to defects in babies of infected mothers $[5,7$, $8,9]$. The Virus latently persists in the body throughout life and the virus is shaded out through the various body fluids [10].

The Virus is transmitted through close contact with body fluids of an infected person like blood transfusion, organ transplant, sexual intercourse, from mother to foetus, saliva, urine and fomites $[11,12,13]$. Therefore, a woman who is infected with Cytomegalovirus during pregnancy can transmit the infection to her foetus $[14,15]$.

Cytomegalovirus causes Viral congenital infection at any stage of pregnancy leading to congenital defects, which can either be primary or recurrent [7]. Most infections caused by cytomegalovirus subclinical including those acquired in utero and during the first months of post natal life, but can cause diseases of diverse severity. Most at times the infection occur during pregnancy does not have consequences to the mother, it can have a serious effect on the foetus $[2,16]$.

Some of them develop an infectious mononucleosis/glandular fever-like syndrome with prolonged fever, mild hepatitis, and sore throat. After the infection the virus remains latent in the body for life [10].

The infection poses important public health problem because of its frequency in severe congenital anomalies [17]. The congenital infections can result to microcephaly, intrauterine, growth retardation, mental retardation, inguinal hernia in a male, seizure, loss in hearing and neuromuscular anomalies [18]. However $90-95 \%$ of infants with congenital CMV infections are asymptomatic at birth. Most congenital CMV infections go unnoticed in the nursery this because the majority of infected new born babies is asymptomatic at birth [19].

Hearing loss is one of the common congenital CMV infection occurring in 10-15\% of infected children [20, 21, $22,23]$. This has lead to screening for hearing of newborn babies, which has been recognized as an essential component of public health care of Childhood in developed countries. However, such screening is yet to be widely embraced in developing countries [24].

The virus therefore causes congenital infections with bilateral or unilateral sensor neural hearing impairment [25]. Therefore, permanent hearing loss is a common sensory disorder in Nigerian children. It impedes the speech, language and cognitive development essential for optimal education and vocational attainment in early childhood [24].

During pregnancy, women infected with the virus has $40 \%$ risk of transmitting it to their foetus at any stage of the pregnancy $[14,26,27]$. However studies suggested that babies are likely to develop complications when their mother are infected in the first 20 weeks of pregnancy [26, 27]. Although fetal damage seldom results from reactivating maternal infection. The extend of disease on new born, however depends on the maternal immune status $[28,26]$.

According to Okwori et al 2008, CMV prevalence is greater in the second trimester than first and third trimester. Congenital infection can result in disabilities such as unilateral sensor neural hearing loss [2, 14].

In UK congenital CMV infection account for $15-20 \%$ of sensor neural hearing loss and $7 \%$ of Cerebral palsy $[19,31$, 32]. While in the US it has been estimated to be around $1 \%$ of live birth and rates of $0.15-2.2 \%$ have been reported [2].

In Singapore, Thailand, Iran, Turkey and Spain the seroprevalence rate of CMV IgG antibodies among pregnant women was reported at $87 \%, 100 \%, 93 \%, 98.5 \%$ and $84 \%$ respectively $[33,34,35,36]$. Cytomegalovirus has been reported as $91 \%$ in adults who are 80 years of age and older [37].

In Nigeria Cytomegalovirus has been reported as $45 \%$ and $33 \%$ in breast milk, $86.15 \%$ (IgG) among expected mothers, $77.1 \%$ (IgG) among primigravid women in Bida, 97.2\% (IgG) among pregnant women in Lagos, and $10.5 \%$ (IgM) among pregnant women in Kafanchan Kaduna State [30, 38, 39, 40]. According to Spring, $199850 \%$ of babies born with symptoms of CMV infections and $15 \%$ of babies born with asymptomatic CMV infection will develop some degree of hearing loss [8].

Congenital seizures disorder account for $10 \%$ of babies born with symptomatic CMV infection and it is a very common abnormality associated with CMV infections. It is usually associated with children severely affected with sytomatic CMV infections of the nervous system. Such children also have other clinical neurological findings such as intracranial calcification, microcephaly and chorioretinitis. The seizure is ovious at birth and can be present at any time within six months of life and the severity varies from child to child, described as mild, moderate, or severe [8].

\section{Methodology}

\subsection{Study Area}

Kaduna is the capital of Northern Region States with coordinates at $10^{\circ} 32^{\prime} 23^{\circ} \mathrm{N} 7^{\circ} 26^{\prime} 25^{\circ} \mathrm{E}$ North-west Nigeria with total area of $131 \mathrm{Km}^{2}$ (51sq mi). Federal Neuropsychiatric Hospital Kaduna State is an internationally renowned mental health institution in quality service delivery, training of mental health professionals and, research in mental health and related fields. patients who are diagnosed clinically of seizure from ages $0-13$ years.

\subsection{Sample Size}

The sample size was calculated using the descriptive studies formula, this is to develop a particular health outcome attribute [46].

\subsection{Ethical Issues}

The research and ethics committee of the National Ear Care Centre Kaduna approved this study, with consent form issued to the patients to seek their or parent/guardian consent. 


\subsection{Selection Cateria}

A simple well structured questionnaire was designed to collect the demographic data of all the subject. Paediatric patients within ages 0-13 years. Patient that are clinically diagnosed with hearing impairment, Patient/Guidian that gives consent for the investigation

\subsection{Sample Collection}

Two mililiters of blood were collected via the ante cubical vein using sterile vacutainer into a plain tube and labelled appropriately. The blood was centrifuged at 3000rpm for 5 minutes. The sera was harvested into clean cryo-vials and stored at $-20^{\circ} \mathrm{C}$ until is ready for use.

Duration of Sample Collection: The Sample was collected immediately after receiving the ethical approval for the number of samples needed

\subsection{Detection of IgG Antibodies Using Enzyme Linked Immunosorbent Assay (ELISA)}

Samples were analyzed for the presence of $\operatorname{IgG} / \operatorname{IgM}$ antibodies using the Enzyme Linked Immunosorbent Assay (ELISA) according to manufacturer's instruction made by
ASIA -LION Biotechnology Company China

\section{Result}

A total of 77 samples was collected from Patients diagnosed of Hearing impairment at National Ear Care Centre Kaduna between ages 0-13 years and screened for Cytomegalovirus IgG and IgM specific antibodies.

Table 1 Shows the summary result of patients with hearing impairment screened for CMV IgG and IgM specific antibodies. The table shows that 77 patients with $35(45.5 \%)$ male and $42(54.5 \%)$ female were screened. Out of which $62(80.5 \%)$ were IgG specific antibodies positive, while $15(19.5 \%)$ were IgG specific antibodies negative. The table also shows that none were positive for IgM specific antibodies.

Table 2 shows the result of patients based on their gender status. The male patients in this table shows 21 $(60 \%)$ were positive while $14(40 \%)$ were negative for CMV IgG specific antibodies. The female is $33(78.5 \%)$ positive and 9 (21.4\%) negative for CMV IgG specific antibodies. The CMV IgM specific antibodies shows non where positive.

Table 1. Showing summary of hearing impairment on CMV.

\begin{tabular}{|c|c|c|c|c|c|c|c|}
\hline \multirow{2}{*}{ Age Group } & \multirow{2}{*}{ Total } & \multicolumn{2}{|l|}{ Sex } & \multicolumn{2}{|l|}{ IgG } & \multicolumn{2}{|l|}{ IgM } \\
\hline & & M & $\mathbf{F}$ & Positive & Negative & Positive & Negative \\
\hline $0-4$ & 31 & 19 & 12 & 28 & 3 & 0 & 31 \\
\hline $5-8$ & 28 & 8 & 20 & 24 & 4 & 0 & 28 \\
\hline $9-13$ & 18 & 8 & 10 & 10 & 8 & 0 & 18 \\
\hline TOTAL & $77(100 \%)$ & $35(45.5 \%)$ & $42(54.5 \%)$ & $62(80.5 \%)$ & $15(19.5 \%)$ & $0(0)$ & $77(100 \%)$ \\
\hline
\end{tabular}

$\mathrm{X}^{2}=0.028 \mathrm{df}=1 \mathrm{p}<0.05$ statistically significant

Table 2. Showing the relationship between gender and CMV $\operatorname{Ig} G / \operatorname{Ig} M$.

\begin{tabular}{|c|c|c|c|c|c|}
\hline \multirow{2}{*}{ Sex } & \multirow{2}{*}{ Total } & \multicolumn{2}{|l|}{ IgG } & \multicolumn{2}{|l|}{ IgM } \\
\hline & & Positive (\%) & Negative (\%) & Positive (\%) & Negative (\%) \\
\hline MALE & $35(45.5)$ & $21(60)$ & $14(40)$ & $0(0)$ & $35(100)$ \\
\hline FEMALE & $42(54.5)$ & $33(78.5)$ & $9(21.4)$ & $0(0)$ & $42(100)$ \\
\hline TOTAL & $77(100)$ & $54(70.1)$ & 23 (29.9) & $0(0)$ & $77(100)$ \\
\hline
\end{tabular}

$\operatorname{IgG}=\mathrm{X}^{2}=0.00, \mathrm{df}=1 \mathrm{p}<0.05$ statistically significant

$\mathrm{IgM}=\mathrm{X}^{2}=0.062, \mathrm{df}=1 \mathrm{p}<0.05$ statistically significant

\section{Discussion}

Cytomegalovirus infection is commonly spread in developing countries and countries that has a low social economic status and represents the most significant viral cause of birth defect in industrialized countries [37]. Primary CMV infection is known to occur in $0.5-2.0 \%$ of all pregnancies worldwide and may be transmitted to fetus in $40 \%$ of all cases [11].

Infants who are not infected congenitally or prenatally with $\mathrm{CMV}$ are at high risk of acquiring the infection in daycare centers. According to some studies, the prevalence of CMV infection in children who attend daycares, particularly children younger than 2 years, is approximately $80 \%$. [41, 28].

A prevalence of $80.5 \% \mathrm{CMV}$ (IgG) specific antibodies was reported in this study. This agrees with the findings of some previous studies, who reported a prevalence of $80.7 \%$ and detected CMV IgG in samples of 94 mothers, 93 (98.9\%) were positive, while their corresponding newborns had $86.2 \%$ (81 out of 93) sero prevalence rate [41, 42]. Yeroh et $a l$. , (2014) Recorded the prevalence rate also agreed with the findings of $94.8 \%$ CMV IgG among pregnant women in Kaduna State Nigerian [43]. It is also in agreement with studies done in Singapore, Thailand, Iran, Turkey and Spain who reported the sero-prevalence rate of CMV IgG antibodies among pregnant women at $87 \%, 100 \%, 93 \%$, $98.5 \%$, and $84 \%$ respectively $[33,34,35,36]$.

Therefore, there is justification on high rate CMV in Children which also shows that CMV is spread world wide. Studies have revealed that Cytomegalovirus is found throughout all geographic locations and infect between 50- 
$80 \%$ of people in the United State as indicated by the presence of antibodies in much of the general population [36, 40].

In Nigeria, a study conducted in 2008, reported a prevalence of $45.0 \%$ and $33 \%$ IgM antibodies among breastfeeding mothers and their infants [38]. Similarly, a study carried out in Kafanchan among pregnant women reveals prevalence of $10.5 \%$ of $\operatorname{IgM}$ specific antibodies [40]. This is not in agreement with the present study which revealed a Sero-prevalence of $0 \%$ CMV IgM specific antibodies. Also, in a study among expectant mothers in Bida, Nigeria, reported IgG antibody prevalence of $86.1 \%$ among multigravid women and $77.1 \%$ among primigravid women was repoted [30]. This is similar to this study that reported $80.5 \%$ IgG CMV specific antibodies.

Serological screening of Cytomegalovirus (CMV) is not a routine examination among women attending antenatal clinic in Nigeria, which could help in reducing transmission from mother to child [40].

The study also shows that Ages 0-4 has the highest frequency with $28(90.3 \%)$ positive with CMV IgG specific antibody followed by ages 5-8 with 24 (85.7\%), and 9-13 years having $10(55.6 \%)$ positive for IgG. The IgM specific antibodies were not dictated in all the patients. This agreed with the work of Redwan et al., that the CMV Sero prevalence increases gradually with age and there is the possibility of acquiring the virus after birth [42].

Several Studies have used retrospective newborn assessments among children with diagnosed sensorineural hearing loss (SNHL) to determine the fraction of cases of hearing impairment caused by congenital CMV infection. Research reported congenital CMV infection in $17 \%$ of children with hearing impairment greater than $40 \mathrm{~dB}$. This group included $10 \%$ of children with hearing loss detected soon after birth and $30 \%$ of children with hearing loss of unknown etiology who were diagnosed more than three months after birth [44].

Ogawa and his collegues analyzed, stored dried umbilical cord samples from 67 children diagnosed with severe SNHL; $15 \%$ were found to have a congenital CMV infection and 55 children who had moderately severe to profound bilateral SNHL ( $>55 \mathrm{~dB}), 16 \%$ had congenital CMV infection also the subset of 36 children with profound bilateral SNHL $(>90$ dB), 22\% were identified with congenital CMV infection [45].

Therefore CMV-related hearing losses do not usually have peculiar audiometric configuration and the hearing loss may be present at birth or occur in the first years of life. Hearing loss from congenital CMV infection can be either unilateral or bilateral and varies from mild to profound. In addition, CMV-related hearing loss may be fluctuating and/or progressive. In fact, approximately half of the cases of hearing loss due to congenital CMV infection are late-onset or progressive therefore, will not be detected at birth through newborn hearing screening [46, 47].

In addition, CMV-related hearing losses may also be progressive or late-onset, requiring more frequent audiological monitoring of infants and young children who have been diagnosed with congenital CMV infection [47].

In this study, patients diagnosed of Hearing impairment 62 $(80.5 \%)$ were positive for CMV IgG specific antibodies, while non was positive for patients diagnosed of Hearing Impairment for CMV IgM specific antibodies.

This studies further reveals females having $78.5 \%$ and males $60 \%$, which is evident that both males and females are susceptible to CMV infection [42]. CMV usually infects the brain cells, resulting to CMV encephalitis. Symptoms include dizziness, hearing impairment headaches, seizures, personality changes and nervous system problems. Sometimes death can occur within weeks or months when CMV infects the nervous system, it is called polyradiculopathy $[31,32]$.

This suggests that Hearing impairment have a significant negative effect on children especially on their social well being, and educational carrier which cause them not to maximise their inherent potentials.

\section{Conclusion}

The evidence from this study suggest CMV infection is prevalent among patients with hearing impairment and could have effect to their social economic and political status of the patients. Therefore, there is a need for routine screening of women of Child bearing age, awareness campaign of the infection, especially among daycares and crèche workers to avoid spread of the disease and prevent inherent danger that comes with it especially on children.

\section{Acknowledgements}

I wish to acknowledge Dr. A Olabobode (Late), Management and Staff of Medical Laboratory Services of National Ear Care Center Kaduna, Nigerian for their tremendous support towards this work.

\section{References}

[1] Prescott, M. L.; Harley, J. P.; and Klein, D. A; (2005): Statement in: Microbiology. 6th Edition pp. 862.

[2] Nathalie, J. S.; Richard, W. E. (2005): Statement in: Diagnostic Procedures for Viral, Rickettsia and Chlamydial Infections 6th Edition pp. $321-329$.

[3] Boppana, S. B.; Rivera, L. B.; Fowler, K. B.; Mach, M. and Britt, W. J. (2001): Intrauterine Transmission of Cytomegalovirus to Infants of Women with Preconceptional Immunity. New England Journal of Medicine. 3334: 1366 $1371(s)$.

[4] Griffiths, P. D. and Walter, S. (2005): Cytomegalovirus. Current opinion in infectious Disease 18 (3): 242-245.

[5] Bello, C. and Whittle, H. (1991): Cytomegalovirus infection in Gambian mothers and their Babies: Journal of Clinical Pathology 1991; 44: 366-369. 
[6] Timbury, C. M. (1986): Herpes Disease: In: Notes on Medical Virology $8^{\text {th }}$ Edition: pp 88- 89.

[7] Fowler, K. B.; and Boppana, S. B. (2006). Congenital cytomegalovirus (CMV) infection and hearing deficit. Journal of Clinical Virology, 35 (2), 226-231.

[8] Spring, 1998: Cytomegalovirus Registry Stagno, S.; Pass, R. F.; Cloud G. Brith; W. J.; Henderson, R. F.; Walton, P. O.; Veren, D. A.; Page, F.; Alford C. A. (1986): Primary Cytomegalovirus infection in pregnancy incidence, transmission of foetus and clinical outcome.; Journal of the American Medical Association 256: 1904-1908.

[9] Gabrielli, L.; Lazzaroho, T.; Foschini, M. P.; Lanari, M.; Guerra, B.; Eusebi, V. and Poala, M. (2003): Horizontal in utero acquisition of cytomegalovirus infection in a twin pregnancy. Journal of clinical microbiology: 14 (3) 1329 $1331(s)$.

[10] Bottieau, E.; Clerinx, J.; Van den Enden, E. (2006): Infectious mononucleosis-like syndromes in febrile travellers returning from the Tropics. Journal of Travel Medicine; 13 (4): 191197.

[11] Stagno S, Pass RF, Cloud G, Brith WJ, Henderson RF, Walton PO, Veren DA, Page F, Alford CA. Primary Cytomegalovirus infection in pregnancy incidence, transmission of foetus and clinical outcome.; Journal of the American Medical Association. 1986; 256: 1904-1908.

[12] Dworsky, M. E.; Welch, K.; Cassady, G. and Stagno, S. (1983). Occupational risk for primary cytomegalovirus infection among paediatric health-care workers. New England Journal of Medicine, 309 (16), 950-953.

[13] HO, M. (1990) Epidemiology of Cytomegalovirus infection. Reviews of Infectious Diseases; 12 (7): 5701-5710.

[14] Colugnati, A. B. F.; Stephanie, A. S. S.; Sheila, C. D. and Michael, J. C. (2007): Incidence of Cytomegalovirus infection among the general population and pregnant women in the United States. doi: 10. 1186/1471-2334-7-71.

[15] Ahmad, R. M.; Kawo, A. H.; Udeani, T. K. C.; Manga, S. B.; Ibrahim, M. L.; and Danjuma, B (2011): Sero-prevelence of cytomegalovirus antibodies in pregnant women attending two Hospitals in Sokoto State, North West Nigeria; Bayaro Journal of pure and applied Science, 4 (1); 63-66.

[16] Ryan, K. J. and Ray, C. G. (2004): Statement in Sherris Medical Microbiology (4th Edition) McGraw- Hill 556; 556559.

[17] Jawetz, M. and Adelberg (2007): Statement in: Text Book Medical Microbiology 24th Edition. Pp. 441 - 445.

[18] Fowler, K. B.; Dahle, A. J.; Boppana, S. B. and Pass, R. F. (1999). New-born hearing screening: will children with hearing loss due to congenital cytomegalovirus infection be missed? Journal of Paediatrics, 135: 60-64.

[19] Morton, C. C. and Nance, W. E. (2006): New-born hearing screening-a silent revolution. New England Journal of Medicine, 354: 2151-2164.

[20] Dahle, A. J.; Fowler, K. B.; Wright, J. R.; Boppana, S. B.; Britt, W. J.; and Pass, R. F. (2000): Longitudinal investigation of hearing disorders in children with congenital cytomegalovirus. Journal of the American Academy of Audiology, 11: 283-290.
[21] Ross, D. S. (2006): Mild and Unilateral hearing loss in children. Access Audiology 5 (2) pp 6.

[22] Fowler, K. B. and Pass, R. F. (2006): Risk factors for congenital cytomegalovirus infection in the offspring of young women: Exposure to young children and recent onset of sexual activity. Paediatric; 118: 286-292.

[23] Kerry, B. T., Morrow, A., Geraghty, S., Huey, N. Sapsford, A., Schleiss, M. R. (2006): Breast milk as a source of acquisition of cytomegalovirus (HCMV) in a premature infant with sepsis syndrome: detection by real - time PCR Journal of clinical Virology; 35 (3): 33-6.

[24] Olusanya, B. O.; Luxan, L. M.; Wirz, S. L. (2005): Screening for early childhood hearing loss in Nigeria: $J$ Med Screen; 12 : 115-118.

[25] Valerie, E. N. (2006): Community Ear and Hearing Health Publications; Issue NO 3, 3: pp 1-16 The Heyford Press Ltd ISSN 1743-9914.

[26] Hollier, L. M. and Grissom, H. (2005): Human Herpes viruses in pregnancy: Cytomegalovirus, Epstein Bar virus and Varicella Zooster virus. Clinics in Perinatology; 32: 71-696.

[27] Duff, P. (2005): Immunotherapy for congenital Cytomegalovirus infection: New England Journal of Medicine; 353 (13): 1402-1404.

[28] Brooks, G. F.; Butel, J. S. and Morse, S. A. (2007): Herpes Viruses In: Jawetz, Melnick and Adelberg's (Ed) Medical Microbiology. 24th Edition, McGraw-Hill. New York 441445 .

[29] Schleiss, M. R., (2008): Prospects for development and impact of a vaccine against congenital cytomegalovirus infection. Journal of Pediatrics; 151: 564-70.

[30] Okwori, A.; Olabode, A.; Emmuwen, E.; Lugos, M.; Okpe, E.; Okopi, J. and Adetunji, j. (2008): Sero- Epidemiological Survey of human cytomegalovirus infection among expectant mothers in Bida Nigeria. The Internet Journal of infectious Diseases; 6 (2).

[31] Grosse, S. D.; Dollard, S. C.; Ross, D. S.; (2008) Congenital cytomegalovirus (CMV) infections a cause of permanent bilateral hearing loss: A quantitative assessment. Journal of Clinical Virology. E- pub ahead of print.

[32] Lazzarotto, T., Verani, S. Guerra, B. Nicolosi, A., Lanrari, M, Landini, M. P. (2001): Prenatal indicators of cytomegalovirus infection. Journal of paediatrics; (13791): 90-5.

[33] Wang, A.; Tank, H.; Tee, C. S. (2000): Seroprevalence of Cytomegalovirus, Toxoplasmosis, and Parvovirus in pregnancy. Singapore Med J.; 41 (4): 151-155.

[34] Arabpou, M.; Kariyanee, K.; Jankhah, A.; (2007). Human cytomegalovirus in women of child bearing age throughout Fars province-Iran: A. population based cohort study. Malaysian Journal of Microbiology.; 3 (2): 23-28.

[35] Ali, S.; Askin, G.; Hakan, O; (2007): CMV seroconversion in pregnancy and the incidence of congenital CMV infection. Turk J Peadriatr.; 49: 30-36.

[36] Estripeant, D.; Moreno, Y.; Ahumada, R. (2007): Seroprevalence of Cytomegalovirus infection in peuperal women and its impact on their newborns. Ann Pediatr.; 66: $135-139$. 
[37] Staras SA, Dollard SC, Rayford KW, Flanders WD, Pass RF, Cannon MJ. (2006) Seroprevalence of Cytomegalosvirus infection in the United State (1988-1994). Clinical Infectious Diseases.; 43 (9): 1143- 1151.

[38] Kassim O. O.; Afolabi, O.; Ako-Nai, K. A.; Torimiro, S. E. A.; Littleton, G. K.; Oke, O. O.; Grisson, F. C.; (1987): Cytomegalovirus antibodies in breast milk and sera of motherinfant pairs. J Trop Pediatr; 33 (2): 75-77.

[39] Akinsegun, A. A.; Kabiru, A. R.; Adeniyi, A. A.; Kikelomo, O. W. (2011) Sero prevalence of Cytomegalovirus antibodies amongst normal pregnant women in Nigeria. Int. $J$ Women Health 2011; 3: 423-428.

[40] Edward, Deborah S., Edward, Isaac U., Nwankiti, O. Shallangwa, Ishaku B., Abdullahi, Musa M., (2015): The Sero-Prevalence of Cytomegalovirus (IgM) Antibodies among Pregnant Women Attending Ante-natal Clinic at the General Hospital Kafanchan, Kaduna State Nigeria. British Microbiology Research Journal; 2015, Vol 9 (5) pp 1-6, 2015. Article no. BMRJ. 16863 ISSN: 2231-0886. DOI: 10.9734/BMRJ/2015/16863.

[41] Adisa, T. Bukbuk, D. Harry, T. (2010): Maternofoetal transfer of Cytomegalovirus $\operatorname{IgG}$ antibodies in Maiduguri, North
Eastern Nigeria. The Internet Journal of Microbiology. Volume 9 Number 1. DOI: $10.5580 / c 53$.

[42] Redwan, A. N. Ahmed, M. M. AlAwfi, M. S. (2011) Prevalence Study of Cytomegalovirus infection among foreign man power in Jeddah Saudi Arabia; African Journal of Microbiology Research Vol 5 (17) pp 2539-2549.

[43] Yeroh, M. Aminu, M. Musa, B. O. (2014): Seroprevalence of Cytomegalovirus infection among Pregnant Women in Kaduna Nigeria. African Journal of Clinical and Experimental Microbiology Vol 16 (1) 37-44.

[44] Barbi M., Binda, S., Caroppa, S., Amborestti, U., Corbetta, C., Sergi, P. (2003). A wider role for congenital cytomegalovirus infection in sensorineural hearing loss. Pediatric Infectious Disease Journal, 22 (1), 39-42.

[45] Ogawa, H., Suzutani, T., Baba, Y., Koyano, S., Nozawa, N., Ishibashi, K., (2007) Etiology of severe sensorineural hearing loss in children: independent impact of congenital cytomegalovirus infection and GJB2 mutations. Journal of Infectious Diseases, 195 (6), 782-8.

[46] Center for Disease Control (CDC) USA, Principles of Epidemiology in Public Health Practice Third Edition (2012). 